\title{
CARDIOVASCULAR RISK ASSESSED BY REYNOLDS RISK SCORE IN RELATION TO WAIST CIRCUMFERENCE IN APPARENTLY HEALTHY MIDDLE-AGED POPULATION IN MONTENEGRO
}

\author{
Aleksandra Klisić ${ }^{1}$, Nebojša Kavarići ${ }^{1}$, Bojko Bjelakoviće ${ }^{2}$, Milovan Jovanović ${ }^{1}$, \\ Elvir Zvrko ${ }^{3}$, Verica Stanišić ${ }^{3}$, Ana Ninićc and Anđelka Šćepanović ${ }^{5}$
}

${ }^{1}$ Primary Health Care Center, Podgorica, Montenegro; ${ }^{2}$ University Department of Pediatrics, Faculty of Medicine, University of Niš, Niš, Serbia; ${ }^{3} \mathrm{Clinical}$ Center of Montenegro, Podgorica, Montenegro; ${ }^{4}$ Department of Medical

Biochemistry, University of Belgrade, Faculty of Pharmacy, Belgrade, Serbia; ${ }^{5}$ Department of Biology,

Faculty of Natural Science and Mathematics, University of Montenegro, Podgorica, Montenegro

SUMMARY - Reynolds Risk Score (RRS) is regarded as a good screening tool for cardiovascular disease (CVD) risk. Since CVD is the leading cause of death in Montenegro, we aimed to assess the risk of CVD as assessed by RRS and to examine its association with cardiometabolic parameters in apparently healthy middle-aged population. In addition, we aimed to test whether obesity had an independent influence on RRS. A total of 132 participants (mean age $56.2 \pm 6.73$ years, $69 \%$ females) were included. Body mass index (BMI), waist circumference (WC), blood pressure (BP) and biochemical parameters (fasting glucose, insulin, lipid parameters, creatinine and high sensitivity C-reactive protein) were determined. Insulin resistance (HOMA-IR) and glomerular filtration rate (eGFR) were calculated. Compared with females, a significantly higher number of males were in the high RRS subgroup $\left(\chi^{2}=45.9, p<0.001\right)$. Furthermore, significantly higher fasting glucose $(p=0.030)$, insulin, HOMA-IR, triglycerides ( $\mathrm{p}<0.001$ all), anthropometric parameters (e.g., BMI and WC; $\mathrm{p}=0.004$ and $\mathrm{p}<0.001$, respectively), and creatinine, but lower eGFR and HDL-c ( $\mathrm{p}<0.001$ both) were recorded in the high-risk subgroup compared with low and medium risk subgroups. In all participants, in addition to LDL-c, diastolic BP and creatinine, WC was independently positively associated with RRS $(\beta=0.194, p=0.006 ; \beta=0.286, p=0.001 ; \beta=0.267, p=0.001$; and $\beta=0.305, p=0.019$, respectively), and $40 \%$ of variation in RRS could be explained with this model. In conclusion, middle-aged population with higher WC should be screened for RRS in order to estimate CVD risk.

Key words: Cardiovascular diseases; Risk factors; Body mass index; Waist circumference; C-reactive protein; Obesity; Cause of death; Montenegro

\section{Introduction}

Cardiovascular disease (CVD) is regarded as the leading cause of death in Montenegro, accounting for

Correspondence to: Aleksandra Klisic, $M D, P h D$, Primary Health Care Center, Trg Nikole Kovačevića 6, 81000 Podgorica, Montenegro

E-mail: aleksandranklisic@gmail.com

Received March 8, 2017, accepted January 18, 2018 more than half of overall mortality (58.6\%). Moreover, an increased prevalence of CVD has been reported in women $(52.2 \%)$ compared with men $(47.8 \%)^{1}$. Early detection of cardiovascular risk burden is of paramount importance for better targeting and treatment of individuals that are prone to CVD, as well as for preventing adverse cardiovascular outcomes ${ }^{2}$. In this sense, many algorithms for estimating CVD risk have been validated so $\mathrm{far}^{3,4}$. 
The first Framingham Risk Score (FRS) included traditional risk factors (i.e. age, gender, total cholesterol level (TC), high-density lipoprotein cholesterol level (HDL-c), systolic blood pressure (SBP), and whether the patient is treated or not for hypertension, diabetes, and smoking) ${ }^{5}$. It estimated the 10 -year risk for coronary heart disease (CHD). The updated version excluded diabetes because diabetes type 2 (DM2) was considered a CHD Risk Equivalent, having the same 10 -year risk as individuals with prior $\mathrm{CHD}^{6}$.

On the other hand, inflammation is regarded to be the underlying mechanism of atherosclerosis, from atheroma formation, progression and destabilization of the plaque until its rupture ${ }^{4}$. Therefore, the quest for biomarkers of inflammation which might add significant contribution to CVD risk assessment has led to validation of another CVD risk score, e.g., Reynolds Risk Score (RRS). Namely, the mentioned score includes parental history of myocardial infarction or stroke $\mathrm{f}^{7}$, as well as high sensitivity $\mathrm{C}$-reactive protein (hsCRP) as the best validated inflammation biomarker so far ${ }^{4}$.

Indeed, both RRS and FRS predict onset and progression of subclinical atherosclerosis ${ }^{8}$. However, RRS has been shown to improve CVD risk prediction compared to FRS in both females and males ${ }^{8,9}$.

Similarly, many other population-based studies in subjects free of known CVD confirmed the superiority of hsCRP above standard risk factors for risk prediction $^{10,11}$. On the contrary, hsCRP has been reported to contribute little to CVD risk prediction compared to traditional risk factors ${ }^{2}$. In addition, hsCRP was only mildly associated with carotid intima-media thickness in the absence of obesity ${ }^{12}$.

To our knowledge, there are no data on the use of RRS in CVD risk assessment among apparently healthy middle-aged population in Montenegro. Taking into account the high prevalence of CVD and mortality, we aimed to assess the CVD risk as estimated by RRS to examine its association with cardiometabolic parameters in middle-aged otherwise healthy Montenegrin population. In addition, we aimed to test whether obesity had an independent influence on RRS.

\section{Materials and Methods}

\section{Study population}

This cross-sectional study enrolled 132 middleaged volunteers (mean age $56.2 \pm 6.73$ years, $69 \%$ fe- males). The subjects were recruited in the Primary Health Care Center in Podgorica, Montenegro, during their regular check-up, in a period from March 2013 to October 2013.

The criteria for inclusion in the study were as follows: volunteers without signs and symptoms of acute inflammatory disease, with preserved kidney function (e.g., estimated glomerular filtration rate (eGFR) $\geq 60 \mathrm{~mL} / \mathrm{min} / 1.73 \mathrm{~m}^{2}$ and with urinary albumin excretion (UAE) $<30 \mathrm{mg} / 24 \mathrm{~h}$ ), and who self-reported to be free of CVD, stroke and DM2. Parental history of myocardial infarction or stroke was obtained from each participant. The methods and assays used to exclude participants and disorders have been described in detail elsewhere ${ }^{13}$.

All the participants provided their written informed consent. The study protocol was approved by the Ethics Committee of Primary Health Care Center in Podgorica, Montenegro, and the research was carried out in compliance with the Declaration of Helsinki.

\section{Anthropometric measurements}

Basic anthropometric measurements including body height $(\mathrm{cm})$, body weight $(\mathrm{kg})$ and waist circumference (WC) $(\mathrm{cm})$ were obtained, and body mass index (BMI) was calculated, as described elsewhere ${ }^{14}$. Blood pressure (BP) was measured as previously described ${ }^{14}$.

Reynolds Risk Score is based on age, gender, total cholesterol, HDL-c, smoking status, hsCRP level, family history of heart attack in patient's parents before the age of 60 , and SBP. The RRS was calculated for each individual subject in accordance with the score sheet available as on-line calculator at: https://www.cvdriskchecksecure.com/ReynoldsRiskScore.aspx.

Thereafter, the cohort of apparently healthy middle-aged population included in this study were divided into low, medium and high risk subgroups (RRS $<5 \%, 5 \% \leq \mathrm{RRS}<10 \%$, and RRS $\geq 10 \%$, respectively) ${ }^{4}$.

\section{Biochemical analyses}

Biochemical parameters were measured as previously described ${ }^{13,14}$. Blood samples were collected between 7.00 and 9.00 a.m., 12-14 hours after an overnight fast. Serum levels of glucose, creatinine, total cholesterol (TC), HDL-c, low density lipoprotein cholesterol (LDL-c) and triglycerides (TG) were measured using standardized enzymatic procedures, spectrophotometrically (Roche Cobas 400, Mannheim, 
Germany). UAE was measured with turbidimetric assay (Roche Cobas 400, Mannheim, Germany). HsCRP levels were determined using an immunonephelometric assay (Behring Nephelometer Analyzer, BN II, Marburg, Germany). Insulin was measured by chemiluminescent immunometric assay (Immulite 2000, Siemens, Munich, Germany). Homeostasis assessment of insulin resistance (HOMA-IR) and eGFR were calculated as described in detail elsewhere ${ }^{14,15}$.

\section{Statistical analysis}

The SPSS statistical package (version 15.0 for Windows, SPSS, Chicago, IL, USA) was used for statistical analysis of the data, which were expressed as mean \pm standard deviation or median (interquartile range), or counts and percentages. Differences between groups were examined by Student's t test for normally distributed parameters, Mann-Whitney test for nonnormally distributed parameters, or one-way ANOVA, and Kruskal-Wallis non-parametric analysis of variance where appropriate. The $\chi^{2}$-test was used to examine differences between categorical data. The relationship between RRS and other variables was evaluated by Pearson's correlation coefficient (r). Multiple linear regression analysis with enter selection procedure was performed to find the independent factors affecting RRS and to estimate the final predictors of its variability. Variables entered in the multiple linear regression model were normally distributed, showed significant parametric correlation with RRS, and showed no multicollinearity. In all analyses, a $p$ value $<0.05$ was considered as statistically significant.

\section{Results}

Table 1 shows general clinical and biochemical characteristics of the study participants. Males displayed significantly higher RRS. They also showed sig-

\section{Table 1. General characteristics of study participants}

\begin{tabular}{|l|l|l|l|}
\hline Characteristic & Women $(\mathrm{n}=91)$ & Men $(\mathrm{n}=41)$ & $\mathrm{p}$ \\
\hline Age $(\mathrm{years})$ & $56.8 \pm 6.15$ & $54.9 \pm 7.80$ & 0.150 \\
$\mathrm{BMI}\left(\mathrm{kg} / \mathrm{m}^{2}\right)$ & $27.0 \pm 4.45$ & $27.8 \pm 3.96$ & 0.279 \\
WC $(\mathrm{cm})$ & $90.2 \pm 12.82$ & $101 \pm 11.6$ & $<0.001$ \\
Fasting glucose $(\mathrm{mmol} / \mathrm{L})$ & $5.40 \pm 0.38$ & $5.56 \pm 0.41$ & 0.029 \\
Insulin $(\mu \mathrm{IU} / / \mathrm{L})^{\#}$ & $6.36(3.60-11.45)$ & $7.60(3.67-15.52)$ & 0.187 \\
HOMA-IR & $1.54(0.87-2.76)$ & $1.99(0.92-3.95)$ & 0.180 \\
TC $(\mathrm{mmol} / \mathrm{L})$ & $6.13 \pm 1.09$ & $6.10 \pm 1.55$ & 0.900 \\
HDL-cholesterol $(\mathrm{mmol} / \mathrm{L})^{\#}$ & $1.57(1.32-1.93)$ & $1.19(0.88-1.37)$ & $<0.001$ \\
LDL-cholesterol (mmol/L) & $4.01 \pm 1.16$ & $4.01 \pm 1.52$ & 0.989 \\
TG $(\mathrm{mmol} / \mathrm{L})^{\#}$ & $1.21(0.92-1.68)$ & $1.93(1.13-2.64)$ & $<0.001$ \\
Non-HDL-c (mmol/L) & $4.29(3.73-5.19)$ & $4.40(3.65-5.61)$ & 0.545 \\
TG/HDL-c ratio & $0.77(0.49-1.16)$ & $1.57(0.92-2.79)$ & $<0.001$ \\
SBP $(\mathrm{mm} \mathrm{Hg})$ & $134 \pm 16.7$ & $140 \pm 13.8$ & 0.031 \\
DBP $(\mathrm{mm} \mathrm{Hg})$ & $84.1 \pm 11.39$ & $88.2 \pm 9.03$ & 0.322 \\
Creatinine $(\mu \mathrm{mol} / \mathrm{L})$ & $58.2 \pm 10.19$ & $76.4 \pm 11.81$ & $<0.001$ \\
eGFR $\left(\mathrm{mL} / \mathrm{min} / 1.73 \mathrm{~m}^{2}\right)$ & $96.8 \pm 11.26$ & $95.6 \pm 11.01$ & 0.588 \\
UAE $(\mathrm{mg} / 24 \mathrm{~h})^{\#}$ & $6.07(4.93-8.53)$ & $6.65(5.05-9.17)$ & 0.521 \\
hsCRP (mg/L) & $1.05(0.51-2.24)$ & $1.46(0.76-1.78)$ & 0.696 \\
Family history, n (\%) & $17(18.7)$ & $13(31.7)$ & 0.156 \\
RRS $(\%)^{\#}$ & $2.00(1.00-4.00)$ & $10.00(5.75-13.00)$ & $<0.001$ \\
\hline
\end{tabular}

Data are presented as mean \pm standard deviation or "median (interquartile range); BMI = body mass index; WC = waist circumference; HOMA-IR $=$ homeostasis model assessment of insulin resistance TC $=$ total cholesterol; HDL-cholesterol $=$ high density lipoprotein cholesterol; LDL-cholesterol = low density lipoprotein cholesterol; $\mathrm{TG}=$ triglycerides; $\mathrm{SBP}=$ systolic blood pressure; $\mathrm{DBP}=$ diastolic blood pressure; $\mathrm{eGFR}$ = estimated glomerular filtration rate; $\mathrm{UAE}$ = urinary albumin excretion; hs $\mathrm{CRP}$ = high sensitivity $\mathrm{C}$-reactive protein; $\mathrm{RRS}$ $=$ Reynolds Risk Score 
Table 2. Cardiometabolic parameters in subgroups according to cardiovascular risk level

\begin{tabular}{|c|c|c|c|c|}
\hline Parameter & $\begin{array}{l}\text { Low RRS }(<5 \%), \\
\mathrm{n}=77(58.3 \%)\end{array}$ & $\begin{array}{l}\text { Medium RRS (5-10\%), } \\
\mathrm{n}=27(20.5 \%)\end{array}$ & $\begin{array}{l}\text { High RRS }(\geq 10 \%), \\
n=28(21.2 \%)\end{array}$ & $\mathrm{p}$ \\
\hline Age (years) & $54.1 \pm 5.73^{\text {aaa,bbb }}$ & $58.9 \pm 6.68$ & $59.7 \pm 7.16$ & $<0.001$ \\
\hline $\mathrm{BMI}\left(\mathrm{kg} / \mathrm{m}^{2}\right)$ & $26.2 \pm 4.46^{\mathrm{aa}, \mathrm{bb}}$ & $28.8 \pm 3.70$ & $28.6 \pm 3.68$ & 0.004 \\
\hline $\mathrm{WC}(\mathrm{cm})$ & $88.1 \pm 11.85^{\text {aаa,bbb }}$ & $99.6 \pm 11.37$ & $102.3 \pm 12.14$ & $<0.001$ \\
\hline Glucose $(\mathrm{mmol} / \mathrm{L})$ & $5.37 \pm 0.39^{a}$ & $5.53 \pm 0.40$ & $5.58 \pm 0.37$ & 0.030 \\
\hline Insulin $(\mu \mathrm{IU} / / \mathrm{L})^{\#}$ & $5.00(3.52-9.25)^{\text {aaa,b }}$ & $7.90(4.50-15.65)$ & $10.9(6.40-16.15)$ & $<0.001$ \\
\hline HOMA-IR ${ }^{\#}$ & $1.20(0.79-2.28)^{\text {ааа,ь }}$ & $1.99(1.08-3.71)$ & $2.85(1.51-4.14)$ & $<0.001$ \\
\hline $\mathrm{TC}(\mathrm{mmol} / \mathrm{L})$ & $5.92 \pm 1.07$ & $6.42 \pm 0.92$ & $6.37 \pm 1.81$ & 0.099 \\
\hline $\mathrm{HDL}-\mathrm{c}(\mathrm{mmol} / \mathrm{L})$ & $1.65 \pm 0.45^{\text {аaа, }}$ & $1.40 \pm 0.45$ & $1.20 \pm 0.38$ & $<0.001$ \\
\hline LDL-c (mmol/L) & $3.80 \pm 1.10$ & $4.30 \pm 1.06$ & $4.31 \pm 1.76$ & 0.085 \\
\hline $\mathrm{TG}(\mathrm{mmol} / \mathrm{L})^{\#}$ & $1.07(0.89-1.36)^{\text {aаa,bbb }}$ & $1.71(1.28-2.32)$ & $1.96(1.21-2.68)$ & $<0.001$ \\
\hline Non-HDL-c (mmol/L) & $4.27 \pm 1.08^{\mathrm{aa}, \mathrm{bb}}$ & $5.02 \pm 1.08$ & $5.17 \pm 1.80$ & 0.001 \\
\hline TG/HDL-c ratio ${ }^{\#}$ & $0.68(0.47-1.01)^{\text {aaa,bbb }}$ & $1.40(0.82-2.09)$ & $1.57(1.07-2.58)$ & $<0.001$ \\
\hline $\mathrm{SBP}(\mathrm{mm} \mathrm{Hg})$ & $129 \pm 14.9^{\text {aaa,bbb }}$ & $140 \pm 10.2^{\mathrm{a}}$ & $149 \pm 15.1$ & $<0.001$ \\
\hline $\mathrm{DBP}(\mathrm{mm} \mathrm{Hg})$ & $81.1 \pm 10.0^{\text {aaa,bbb }}$ & $88.9 \pm 8.1^{\mathrm{a}}$ & $93.7 \pm 9.43$ & $<0.001$ \\
\hline Creatinine $(\mu \mathrm{mol} / \mathrm{L})$ & $59.7 \pm 12.50^{\text {аaа }}$ & $68.4 \pm 12.2^{\mathrm{aa}}$ & $74.4 \pm 12.2$ & $<0.001$ \\
\hline $\mathrm{eGFR}\left(\mathrm{mL} / \mathrm{min} / 1.73 \mathrm{~m}^{2}\right)$ & $98.7 \pm 10.03$ & $94.3 \pm 14.44$ & $92.1 \pm 8.99$ & 0.013 \\
\hline $\mathrm{UAE}(\mathrm{mg} / 24 \mathrm{~h})^{\#}$ & $5.92(4.91-7.39)^{\mathrm{b}}$ & $7.82(5.11-9.80)$ & $6.96(4.94-10.28)$ & 0.091 \\
\hline hsCRP (mg/L) & $0.80(0.42-1.86)^{\text {ааа,ь }}$ & $1.50(0.56-2.75)$ & $1.76(1.43-2.91)$ & $<0.001$ \\
\hline RRS (\%) & $1.79 \pm 1.15^{\text {aaa,bbb }}$ & $6.00 \pm 1.14^{\text {aаa }}$ & $14.21 \pm 5.30$ & $<0.001$ \\
\hline Overweight/obese, n (\%) & $39(50)$ & $20(74)$ & $20(71)$ & $\begin{array}{l}\chi^{2}=5.11 \\
0.024\end{array}$ \\
\hline Normal weight, n (\%) & $38(49.4)$ & $7(26)$ & $8(29)$ & \\
\hline Gender (F/M), n (\%) & $69 / 8(76 / 19)$ & $16 / 11(18 / 27)$ & $6 / 22(6 / 54)$ & $\begin{array}{l}\chi^{2}=45.9 \\
<0.001\end{array}$ \\
\hline
\end{tabular}

${ }^{\mathrm{a}} \mathrm{p}<0.05 ;{ }^{\mathrm{aa}} \mathrm{p}<0.01 ;{ }^{\text {aaa }} \mathrm{p}<0.001$ vs. high RRS; ${ }^{\mathrm{b}} \mathrm{p}<0.05 ;{ }^{\mathrm{bb}} \mathrm{p}<0.01 ;{ }^{\text {bbb }} \mathrm{p}<0.001$ vs. medium RRS; RRS = Reynolds Risk Score; ${ }^{\# d a t a ~ w i t h ~ n o n-~}$ gaussian distribution are shown as median values (interquartile range); ${ }^{2} \mathrm{p}$ value from one-way ANOVA or Kruskal-Wallis non-parametric analysis of variance, followed by non-parametric Mann-Whitney U test, where appropriate; BMI = body mass index; WC = waist circumference; HOMA-IR = homeostasis model assessment of insulin resistance; TC = total cholesterol; HDL-c = high density lipoprotein cholesterol; LDL-c = low density lipoprotein cholesterol; $\mathrm{TG}=$ triglycerides; $\mathrm{SBP}=$ systolic blood pressure; $\mathrm{DBP}=$ diastolic blood pressure; eGFR = estimated glomerular filtration rate using the Chronic Kidney Disease Epidemiology Collaboration Equation; UAE = urinary albumin excretion; hsCRP = high sensitivity $\mathrm{C}$-reactive protein; $\mathrm{F}=$ female; $\mathrm{M}=$ male

nificantly higher WC, fasting glucose, TG, TG/HDLratio, creatinine and SBP, but lower HDL-c. There was no difference in age, BMI, hsCRP and eGFR between the groups.

In the current study, we aimed to test the association of cardiometabolic parameters (e.g., anthropometric indices, lipid parameters, markers of insulin resistance, renal function markers, and blood pressure) with the risk of CVD (as estimated using the RRS). A significantly higher number of males were in the higher RRS subgroup as compared with females $\left(\chi^{2}=45.9\right.$, $\mathrm{p}<0.001)$. Also, a significantly higher number of over- weight/obese individuals were in the high-risk subgroup as compared with low-risk subgroup $\left(\chi^{2}=5.11\right.$, $\mathrm{p}=0.024)$. Furthermore, we found significant differences in several parameters that are independent of RRS calculation, i.e. significantly higher fasting glucose level $(\mathrm{p}=0.030)$, insulin, HOMA-IR and TG $(\mathrm{p}<0.001 \mathrm{all})$, as well as in anthropometric parameters [e.g., BMI and WC ( $\mathrm{p}=0.004$, and $\mathrm{p}<0.001$, respectively)] in the high-risk subgroup. Moreover, we found significantly higher creatinine, but lower HDL-c and eGFR in the high-risk subgroup as compared with low and medium risk subgroups $(\mathrm{p}<0.001)$. There were 
no gender differences in the prevalence of parental history of myocardial infarction or stroke (Table 2).

Thereafter, we performed Pearson's parametric correlation to examine the potential relationship between RRS and cardiometabolic parameters normally distributed and independent of RRS calculation. RRS correlated positively with anthropometric parameters (BMI and WC), fasting blood glucose, lipid parameters (LDL-c and non-HDL-c), as well as with creatinine concentrations. RRS negatively correlated with the renal function marker (eGFR) (Table 3).

Table 3. Pearson's correlation coefficient (r) of Reynolds Risk Score (RRS) with study parameters independent of $R R S$ calculation in all participants

\begin{tabular}{|l|l|l|}
\hline Variable & $\mathrm{r}$ & $\mathrm{p}$ \\
\hline BMI $\left(\mathrm{kg} / \mathrm{m}^{2}\right)$ & 0.298 & 0.001 \\
WC $(\mathrm{cm})$ & 0.470 & $<0.001$ \\
Fasting glucose $(\mathrm{mmol} / \mathrm{L})$ & 0.282 & 0.001 \\
LDL-c $(\mathrm{mmol} / \mathrm{L})$ & 0.201 & 0.021 \\
Non-HDL-c $(\mathrm{mmol} / \mathrm{L})$ & 0.313 & $<0.001$ \\
DBP $(\mathrm{mm} \mathrm{Hg})$ & 0.463 & $<0.001$ \\
Creatinine $(\mu \mathrm{mol} / \mathrm{L})$ & 0.465 & $<0.001$ \\
eGFR $\left(\mathrm{mL} / \mathrm{min} / 1.73 \mathrm{~m}^{2}\right)$ & -0.282 & 0.001 \\
\hline
\end{tabular}

$\mathrm{BMI}=$ body mass index WC $=$ waist circumference LDL-c $=$ low density lipoprotein cholesterol; non-HDL-c = non-high density lipoprotein cholesterol; $\mathrm{DBP}=$ diastolic blood pressure; $\mathrm{eGFR}=$ estimated glomerular filtration rate using the Chronic Kidney Disease Epidemiology Collaboration Equation
Multiple linear regression analysis was performed to explore which of the measured markers had the best association with RRS. All variables found to have a significant predictive value in Pearson's parametric correlation analysis (BMI, WC, glucose, LDL-c, creatinine and DBP) were further analyzed in multiple linear regression analysis for RRS prediction. NonHDL-c and eGFR were excluded from further analysis due to multicollinearity. With enter selection procedure, the best model consisted of 6 parameters (Table 4). These 6 independent variables statistically significantly predicted RRS in the good-fit data model, $F$ $(6,125)=15.364, p<0.001$. Namely, WC, LDL-c, DBP and creatinine were independently positively associated with RRS $(\beta=0.305, p=0.019 ; \beta=0.194, p=0.006$; $\beta=0.286, p=0.001 ; \beta=0.267$ and $p=0.001$, respectively). Adjusted $\mathrm{R}^{2}$ for the best-fit model was 0.40 , which means that $40 \%$ of variation in RRS could be explained with this model, for all participants. The parameters of multiple regression analysis, unstandardized coefficient (B), its standard error (SE), standardized coefficient $(\beta)$, t value and significance $(p)$ are shown in Table 4.

\section{Discussion}

In the current study, we assessed cardiovascular risk as determined by RRS in apparently healthy middleaged population in Montenegro. Our findings revealed that even $41.7 \%$ of them had medium or high CVD

Table 4. Multiple regression analysis for the association of study parameters with Reynolds Risk score (RRS)

\begin{tabular}{|c|c|c|c|c|c|}
\hline \multirow{3}{*}{ Predictor } & \multicolumn{5}{|c|}{$\begin{array}{l}\text { Dependent variable RRS; } \mathrm{F}(6,125)=15.364, \mathrm{p}<0.001 \\
\mathrm{R}^{2}=0.424 \\
\text { Adjusted } \mathrm{R}^{2}=0.40\end{array}$} \\
\hline & \multicolumn{2}{|c|}{ Nonstandardized } & \multirow{2}{*}{$\begin{array}{l}\text { Standardized } \\
\text { coefficient } \\
\beta\end{array}$} & \multirow[b]{2}{*}{$\mathrm{t}$} & \multirow[b]{2}{*}{$\mathrm{p}$} \\
\hline & $\mathrm{B}$ & Standard error & & & \\
\hline BMI $\left(\mathrm{kg} / \mathrm{m}^{2}\right)$ & -0.211 & 0.153 & -0.163 & -1.375 & 0.172 \\
\hline $\mathrm{WC}(\mathrm{cm})$ & 0.127 & 0.053 & 0.305 & -2.380 & 0.019 \\
\hline Fasting glucose (mmol/L) & 1.722 & 1.038 & 0.122 & 1.659 & 0.100 \\
\hline $\mathrm{LDL}-\mathrm{c}(\mathrm{mmol} / \mathrm{L})$ & 0.847 & 0.300 & 0.194 & 2.821 & 0.006 \\
\hline $\mathrm{DBP}(\mathrm{mm} \mathrm{Hg})$ & 0.147 & 0.041 & 0.286 & 3.574 & 0.001 \\
\hline Creatinine $(\mu \mathrm{mol} / \mathrm{L})$ & 0.109 & 0.032 & 0.267 & 3.365 & 0.001 \\
\hline
\end{tabular}

$\mathrm{BMI}=$ body mass index; $\mathrm{WC}=$ waist circumference; $\mathrm{LDL}-\mathrm{c}=$ low density lipoprotein cholesterol; $\mathrm{DBP}=$ diastolic blood pressure 
risk (20.5\% and 21.2\%, respectively). Moreover, men displayed a significantly higher CVD risk than women, accounting for more than half of males with higher RRS (even 54\%), as compared with males with low and intermediate risk (19\% and 27\%, respectively) (Table 2). Our results are in agreement with other studies, which also reported significantly higher CVD risk in males compared to females ${ }^{16,17}$.

Indeed, both the FRS and the RRS stratify a large number of women to the low-risk category (e.g., 76\% of women were stratified in the low CVD risk in the current study), raising doubts that they may not accurately define an individual's lifetime risk ${ }^{3}$. However, RRS has been shown to improve CVD risk prediction compared to FRS in both females and males?.

In our study, there was no difference in serum hsCRP level between males and females (Table 1), although discrepant results have been reported in other, larger studies ${ }^{18,19}$. Cushman et al. ${ }^{20}$ in their national study showed that RRS classified the population differently than FRS. Namely, almost $50 \%$ of the examined women had increased hsCRP (e.g., $>3 \mathrm{mg} / \mathrm{L}$ ) and were more likely to have this inflammation biomarker increased despite the much lower FRS. DeFilippis et al. ${ }^{8}$ in the Multi-Ethnic Study of Atherosclerosis showed that RRS added additional predictive power for subclinical atherosclerosis incidence and progression, when there was discrepancy between FRS and RRS. Pietka et al. ${ }^{21}$ in a cohort of 119 non-diabetic men with stable coronary artery disease and preserved left ventricular systolic function showed that men with higher RRS had lower frequency of marginal or no atherosclerotic coronary arteries.

On the other hand, several studies report that hsCRP has only a minor contribution to CVD risk prediction compared to traditional risk factors ${ }^{2,22}$. In the JUPITER study that included 6760 participants, Blaha et al. ${ }^{12}$ report that hsCRP was not associated with subclinical atherosclerosis, using coronary artery calcium and was mildly associated with carotid intima-media thickness in the absence of obesity. On the contrary, obesity was associated with both indicators of subclinical atherosclerosis independently of hsCRP level.

Obesity itself is believed to contribute to low-grade inflammation, as adipose tissue has been found to secrete a great variety of proinflammatory adipocytokines. Moreover, abdominal body fat distribution has more atherogenic properties than overall adiposity ${ }^{23,24}$. It is important to note that although we included in our study only apparently healthy participants free of diabetes and CVD, the majority of them were found to be overweight/obese and were stratified in the intermediate or higher CVD risk group (74\% and $71 \%$, respectively) (Table 2).

The results obtained in the current study showed that besides traditional cardiometabolic parameters such as high LDL-c, DBP and creatinine, WC was independently associated with RRS (Table 4). These findings may support the important link between obesity and CVD, and are in accordance with our previous studies conducted in adolescent girls ${ }^{25,26}$ and postmenopausal women ${ }^{1,27}$. However, the results of the current study extended our previous findings, suggesting that the independent association between obesity and increased CVD risk existed in both genders. Furthermore, since FRS that includes traditional CVD markers may underestimate CVD risk ${ }^{28}$, we assessed RRS, taking into account that inflammation may add significant contribution to the increased CVD risk burden $^{25,29}$.

Other studies report similar results. Su et al. ${ }^{16}$ in a study on 882 Malays found WC to correlate strongly with CVD risk in both males and females. In the Filipino-American Women Cardiovascular Study, Ancheta $e t$ al. ${ }^{30}$ showed that increased WC was associated with increased CVD risk scores, suggesting the need for obesity control as primary prevention of CVD. Indeed, Karam et al. ${ }^{17}$ during campaigns for reducing CVD incidence showed that over a 6-year period, several CVD risk factors had decreased, leading to a decrease in the 10-year risk of CVD. Goh et al. ${ }^{31}$ in a representative sample of almost 4500 Australian women aged 20-69 years without CVD, diabetes or stroke report that abdominal obesity measures were better predictors of CVD risk compared with overall obesity measures. Similarly, Park et al. ${ }^{32}$ report on WC to be a more predictive marker of coronary artery calcification than BMI. Pokharel et al. ${ }^{33}$ report on positive association of both BMI and WC with subclinical atherosclerosis.

On the contrary, in a recent study on 610 healthy Iranian adults, Salari et al. ${ }^{34}$ report no independent association between obesity indices and atherosclerosis. In addition, results of a cross-sectional study on 120 subjects undergoing coronary angiography showed 
that anthropometric measurements could not be markers of atherosclerosis in subjects with overweight/ obesity ${ }^{35}$.

Despite discrepant results reported from different studies and many novel biomarkers for CVD risk assessment having been investigated so far, it seems that traditional cardiometabolic markers (e.g., LDL-c, DBP, creatinine), and especially obesity indices (e.g., WC) must not be underscored. Thus, strategies for reducing obesity may be of great importance in decreasing CVD risk.

The current study had some limitations. A relatively small number of participants may be a limiting factor when dealing with CVD risk estimation. Therefore, a national-representative sample study should confirm these results. Moreover, since only apparently healthy middle-aged subjects were included, the prevalence of increased CVD risk in Montenegrin population might be even higher. Furthermore, prospective studies are needed to confirm the causal link between increased CVD risk and obesity, and what is more important, to include prediction of cardiovascular events.

Nevertheless, a significantly high prevalence of overweight/obese individuals who were stratified in the intermediate and high CVD risk groups and the independent relationship between RRS and WC observed in the current study may indicate an urgent need for developing strategies to reduce obesity and hence the CVD risk, morbidity and mortality as well.

\section{Conclusion}

In the middle-aged study population, in addition to LDL-c, diastolic BP and creatinine, WC was independently positively associated with RRS. In addition, even though many novel biomarkers for CVD risk assessment have been investigated so far, it seems that traditional cardiometabolic markers, especially obesity indices, must not be underscored. Thus, strategies for reducing obesity may be of great importance in decreasing CVD risk in primary prevention setting.

\section{Acknowledgment}

This work was financially supported in part by a grant from the Ministry of Education, Science and Technological Development, Republic of Serbia (project number 175035).

\section{References}

1. Klisic AN, Vasiljevic ND, Simic TP, Djukic TI, Maksimovic MZ, Matic MG. Association between C-reactive protein, anthropometric and lipid parameters among healthy normal weight and overweight postmenopausal women in Montenegro. Lab Med. 2014;45(1):12-6. PMID: 24719979

2. Kim HC, Greenland P, Rossouw JE, Manson JE, Cochrane $\mathrm{BB}$, Lasser NL, et al. Multimarker prediction of coronary heart disease risk: the Women's Health Initiative. J Am Coll Cardiol. 2010;55(19):2080-91. doi: 10.1016/j.jacc.2009.12.047

3. Tattersall MC, Gangnon RE, Karmali KN, Keevil JG. Women up, men down: the clinical impact of replacing the Framingham Risk Score with the Reynolds Risk Score in the United States population. PLoS One. 2012;7(9):e44347. doi: 10.1371/journal.pone.0044347

4. Ridker PM, Burning JE, Rifai N, Cook NR. Improving cardiovascular risk prediction for women, development and validation of improved algorithms for the assessment of global cardiovascular risk in women: the Reynolds Risk Score. JAMA. 2007;297:611-9. doi: 10.1001/jama.297.6.611

5. Expert Panel on Detection, Evaluation, and Treatment of High Blood Cholesterol in Adults. Executive summary of the Third Report of the National Cholesterol Education Program (NCEP) Expert Panel on Detection, Evaluation, and Treatment of High Blood Cholesterol in Adults (Adult Treatment Panel III). JAMA. 2001;285:2486-97. PMID:11368702

6. National Cholesterol Education Program (NCEP) Expert Panel on Detection, Evaluation, and Treatment of High Blood Cholesterol in Adults (Adult Treatment Panel III). Third Report of the National Cholesterol Education Program (NCEP) Expert Panel on Detection, Evaluation, and Treatment of High Blood Cholesterol in Adults (Adult Treatment Panel III) final report. Circulation. 2002;106:3143-421. PMID: 12485966

7. Eaton CB, Bostom AG, Yanek L, Laurino JP, McQuade W, Hume A, et al. Family history and premature heart disease. J Am Board Fam Pract. 1996;9(5):312-8. PMID: 8884668

8. DeFilippis AP, Blaha MJ, Ndumele CE, Budoff MJ, LloydJones DM, McClelland R, et al. The association of Framingham and Reynolds risk scores with incidence and progression of coronary artery calcification in MESA (Multi-Ethnic Study of Atherosclerosis). J Am Coll Cardiol. 2011;58:2076-83. doi: 10.1016/j.jacc.2011.08.022

9. Paynter NP, Everett BM, Cook NR. Cardiovascular disease risk prediction in women: is there a role for novel biomarkers? Clin Chem. 2014;60(1):88-97.

doi: 10.1373/clinchem.2013.202796

10. Ridker PM. High-sensitivity C-reactive protein, vascular imaging, and vulnerable plaque: more evidence to support trials of antiinflammatory therapy for cardiovascular risk reduction. Circ Cardiovasc Imaging. 2011;4:195-7. doi: 10.1161/CIRCIMAGING.111.965053

11. Shah KB, Kop WJ, Christenson RH, Diercks DB, Kuo D, Henderson $\mathrm{S}$, et al. Lack of diagnostic and prognostic utility of 
circulating plasma myeloperoxidase concentrations in patients presenting with dyspnea. Clin Chem. 2009;55(1):59-67. doi: 10.1373/clinchem.2008.108159

12. Blaha MJ, Rivera JJ, Budoff MJ, Blankstein R, Agatston A, O'Leary DH, et al. Association between obesity, high-sensitivity C-reactive protein $\geq 2 \mathrm{mg} / \mathrm{L}$, and subclinical atherosclerosis: implications of JUPITER from the Multi-Ethnic Study of Atherosclerosis. Arterioscler Thromb Vasc Biol. 2011;31(6): 1430-8. doi: 10.1161/ATVBAHA.111.223768

13. Kavaric N, Klisic A, Ninic A. Are visceral adiposity index and lipid accumulation product reliable indices for metabolic disturbances in patients with type 2 diabetes mellitus? J Clin Lab Anal. 2018;32:e22283. doi: 10.1002/jcla.22283

14. Klisic A, Kavaric N, Jovanovic M, Soldatovic I, GligorovicBarhanovic N, Kotur-Stevuljevic J. Bioavailable testosterone is independently associated with fatty liver index in postmenopausal women. Arch Med Sci. 2017;5(13):1188-1196. doi: 10.5114/aoms.2017.68972.

15. Bulum T, Blaslov K, Duvnjak L. The use of anthropometric measurements of obesity in prediction of microvascular complications in obese type 2 diabetic patients. Acta Clin Croat. 2016;55:217-23. doi: 10.20471/acc.2016.55.02.06

16. Su TT, Amiri M, Hairi FM, Thangiah N, Dahlui M, Majid HA. Body composition indices and predicted cardiovascular disease risk profile among urban dwellers in Malaysia. BioMed Res Int. 2015;2015:174821. doi: 10.1155/2015/174821

17. Karam C, Beauchet A, Czernichow S, de Roquefeuil F, Bourez A, Mansencal N, et al. Trends in cardiovascular disease risk factor prevalence and estimated 10-year cardiovascular risk scores in a large untreated French urban population: the CARVAR 92 Study. PLoS One. 2015;10(4):e0124817. doi:10.1371/journal.pone.0124817

18. Wang Z, Wang X, Chen Z, Zhang L, Zhu M. Distribution of high-sensitivity $\mathrm{C}$-reactive protein and its relationship with other cardiovascular risk factors in the middle-aged Chinese population. Int J Environ Res Public Health. 2016;13(9):872. doi:10.3390/ijerph13090872

19. Halcox JP, Roy C, Tubach F, Banegas JR, Dallongeville J, De Backer $\mathrm{G}$, et al. C-reactive protein levels in patients at cardiovascular risk: EURIKA study. BMC Cardiovasc Disord. 2014;14:25. doi: 10.1186/1471-2261-14-25

20. Cushman M, McClure LA, Howard VJ, Jenny NS, Lakoski SG, Howard G. Implications of increased C-reactive protein for cardiovascular risk stratification in black and white men and women in the US. Clin Chem. 2009;55(9):1627-36. doi: 10.1373/clinchem.2008.122093

21. Pietka I, Sakowicz A, Pietrucha T, Cichocka-Radwan A, Lelonek M. Usefulness of Reynolds Risk Score in men with stable angina. Cent Eur J Med. 2014;9(1):21-7. doi:10.2478/s11536-013-0240-z

22. Eapen DJ, Manocha P, Patel RS, Hammadah M, Veledar E, Wassel C, et al. Aggregate Risk Score based on markers of inflammation, cell stress, and coagulation is an independent predictor of adverse cardiovascular outcomes. J Am Coll Cardiol. 2013;62:329-37. doi: 10.1016/j.jacc.2013.03.072
23. Martinac M, Pehar D, Karlović D, Babić D, Marčinko D, Jakovljević M. Metabolic syndrome, activity of the hypothalamic-pituitary-adrenal axis and inflammatory mediators in depressive disorder. Acta Clin Croat. 2014;53:55-71. PMID: 24974667

24. Rakočević L, Rakočević V. Incidence of cardiovascular risk factors in obese children. Acta Clin Croat. 2016;55:407-13. doi: 10.20471/acc.2016.55.03.09

25. Klisic A, Kavaric N, Soldatovic I, Bjelakovic B, Kotur-Stevuljevic J. Relationship between cardiovascular risk score and traditional and nontraditional cardiometabolic parameters in obese adolescent girls. J Med Biochem. 2016;35(3):282-92. doi: 10.1515/jomb-2016-0005

26. Klisić A, Kavarić N, Bjelaković B, Soldatović I, Martinović M, Kotur-Stevuljević J. The association between retinol-binding protein 4 and cardiovascular risk score is mediated by waist circumference in overweight/obese adolescent girls. Acta Clin Croat. 2017;56:92-8. doi: 10.20471/acc.2017.56.01.14

27. Klisic A, Kotur-Stevuljevic J, Kavaric N, Matic M. Relationship between cystatin C, retinol-binding protein 4 and Framingham Risk Score in healthy postmenopausal women. Arch Iran Med. 2016;19(12):845-51. doi: 0161912/AIM.006

28. Cook NR, Paynter NP, Eaton CB, Manson JE, Martin LW, Robinson JG, et al. Comparison of the Framingham and Reynolds risk scores for global cardiovascular risk prediction in the multiethnic Women's Health Initiative. Circulation. 2012;125(14):1748-56. doi: 10.1161/CIRCULATIONAHA.111.075929

29. Adukauskienė D, Čiginskienė A, Adukauskaitė A, Pentiokinienė D, Šlapikas R, Čeponienė I. Clinical relevance of high sensitivity C-reactive protein in cardiology. Medicina (Kaunas). 2016;52(1):1-10. doi: 10.1016/j.medici.2015.12.001

30. Ancheta IB, Battie CA, Volgman AS, Ancheta CV, Palaniappan L. Cardiovascular disease risk score: results from the Filipino-American Women Cardiovascular Study. J Racial Ethn Health Disparities. 2017;4(1):25-34. doi:10.1007/s40615-015-0196-6

31. Goh LGH, Dhaliwal SS, Welborn TA, Lee AH, Della PR. Anthropometric measurements of general and central obesity and the prediction of cardiovascular disease risk in women: a crosssectional study. BMJ Open. 2014;4:e004138. doi: 10.1136/bmjopen-2013-004138

32. Park J, Lee ES, Lee DY, Kim J, Park SE, Park CY, et al. Waist circumference as a marker of obesity is more predictive of coronary artery calcification than body mass index in apparently healthy Korean adults: the Kangbuk Samsung Health Study. Endocrinol Metab. 2016;31(4):559-66.

https://doi.org/10.3803/EnM.2016.31.4.559

33. Pokharel Y, Basra S, Lincoln AE, Tucker AM, Nambi V, Nasir $\mathrm{K}$, et al. Association of body mass index and waist circumference with subclinical atherosclerosis in retired NFL players. South Med J. 2014;107:633-9. doi: 10.14423/SMJ.0000000000000173 
34. Salari A, Shakiba M, Mahdavi-Roshan M, Gholipour M, Naghshbandi M, Rajabi R. The association between various indices of obesity and severity of atherosclerosis in adults in the north of Iran. Medicine (Baltimore). 2016;95(50):e5670. doi: 10.1097/MD.0000000000005670
35. Maddaloni E, Cavallari I, De Pascalis M, Keenan H, Park K, Manfrini S, et al. Relation of body circumferences to cardiometabolic disease in overweight-obese subjects. Am J Cardiol. 2016;118:822-7.

doi: 10.1016/j.amjcard.2016.06.044

Sažetak

\section{KARDIOVASKULARNI RIZIK PROCIJENJEN REYNOLDSOVIM ZBIROM RIZIKA U ODNOSU NA OBIM STRUKA U POPULACIJI ODRASLIH ZDRAVIH CRNOGORACA}

\section{A. Klisić, N. Kavarić, B. Bjelakovic, M. Jovanović, E. Zurko, V. Stanišic, A. Ninić i A. Šcepanović}

Reynoldsov zbir rizika (Reynolds Risk Score, RRS) se smatra dobrim algoritmom probira za procjenu rizika od kardiovaskularnih bolesti (KVB). Kako su KVB vodeći uzrok smrtnosti u Crnoj Gori, cilj studije je bio procijeniti KV rizik primjenom algoritma RRS i ispitati njegovu povezanost s kardiometaboličkim čimbenicima rizika u populaciji odraslih zdravih ispitanika. Cilj je također bio ispitati nezavisan utjecaj pretilosti na RRS. U studiju su bile uključene 132 osobe srednje dobi od 56,2 $\pm 6,73$ godine; $69 \%$ su bile žene. Mjereni su sljedeći parametri: indeks tjelesne mase, obim struka, krvni tlak te biokemijski parametri (glikemija natašte, inzulin, lipidni parametri i visoko osjetliiv $\mathrm{C}$-reaktivni protein). Izračunata je inzulinska rezistencija (HOMA-IR) i procijenjena razina glomerularne filtracije (eGFR). U usporedbi sa ženama, značajno veći broj muškaraca bio je u skupini s većim KV rizikom $\left(\chi^{2}=45,9 ; \mathrm{p}<0,001\right)$. Također, značajno veće vrijednosti glikemije natašte $(\mathrm{p}=0,030)$, inzulina $(\mathrm{p}<0,001)$, HOMA-IR $(\mathrm{p}<0,001)$, triglicerida $(\mathrm{p}<0,001)$, antropometrijskih parametara [npr. indeks tjelesne mase ( $p=0,004)$ i obim struka $(p<0,001)]$ i kreatinina $(p<0,001)$, a niže vrijednosti eGFR $(p<0,001)$ i HDL-c $(p<0,001)$ uočene su u podskupini s većim KV rizikom u usporedbi s podskupinama s niskim i srednjim rizikom ( $<<0,001)$. Uz vrijednosti LDL-c $(\beta=0,194, p=0,006)$, dijastoličkog krvnog tlaka $(\beta=0,286, p=0,001)$ i kreatinina $(\beta=0,267, p=0,001)$, obim struka je bio nezavisno povezan s RRS ( $\beta=0,305, p=0,019) ; 40 \%$ varijabilnosti u RRS moglo se objasniti ovim modelom. U zaključ$\mathrm{ku}$, populaciji ispitanika srednje dobi s povećanim obimom struka treba odrediti RRS radi procjene rizika od KVB.

Ključne riječi: Kardiovaskularne bolesti; Rizični čimbenici; Indeks tjelesne mase; Struk, obim; C-reaktivni protein; Pretilost; Uzrok smrti; Crna Gora 